\title{
Where does Sedum cepaea L. (Crassulaceae) - one of the rarest species of Croatian flora - really grow?
}

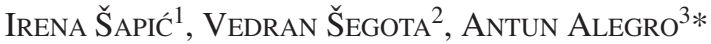 \\ ${ }^{1}$ Department of Ecology and Silviculture, Faculty of Forestry, University of Zagreb, \\ Svetošimunska 25, p.p. 422, 10002 Zagreb, Croatia \\ ${ }^{2}$ Institute for Research and Development of Sustainable Ecosystems, Jagodno 100a, \\ 10415 Novo Čiče, Velika Gorica, Croatia \\ ${ }^{3}$ Department of Botany, Faculty of Science, University of Zagreb, Marulićev trg 20/II, \\ 10000 Zagreb, Croatia
}

\begin{abstract}
The distribution of Sedum cepaea in Croatia is limited to sciophilous or slightly heliophilous forest habitats in the zone dominated by Quercus petraea, developed on acidic types of soil above siliceous bedrock. We confirm a finding spot on Moslavačka gora and describe new localities on Zrinska gora (central Croatia). Two S. cepaea populations on Nikolino brdo [hill] in Topusko disappeared a century ago.
\end{abstract}

Key words: Sedum cepaea, flora, Croatia

\section{Introduction}

The genus Sedum with 428 species is the largest genus of the stonecrop family (Crassulaceae) (EGGLI 2003). It is almost exclusively confined to the subtropical and temperate regions of the Northern Hemisphere ('T HART and EGGLI 2003). In Europe, about 55 species occur throughout the region, with the highest diversity in the Mediterranean region (WeBB et al. 1993, 'T HART and EgGli 2003). In Croatia 27 taxa are known (NiKolić 2010).

Originally an Eastern Mediterranean plant, Sedum cepaea L. (syn. S. galioides All., S. calabrum Ten., S. paniculatum Lam., S. spathulatum Waldst. et Kit.) has extended its area of distribution to parts of Central and Southern Europe ('T HART and EGGLI 2003). It reaches the Iberian Peninsula only as far as Pyrenees and neighbouring areas (CASTROVIEJO and Velayos 2001), while in France it is spread up to the Atlantic (BonNIER 1919-1920, FOURNIER 1961). Therefore, it is sometimes described as a Mediterranean-Atlantic plant. Sedum cepaea is present in Italy, including Sicily and Sardinia (ZÁNgheri 1976, PignatTI

\footnotetext{
* Corresponding author, e-mail: antun.alegro@biol.pmf.hr

Copyright ${ }^{\circledR} 2012$ by Acta Botanica Croatica, the Faculty of Science, University of Zagreb. All rights reserved.
} 
1982, ARRIGONi 2010) and Corsica (JEANMONOD and GAMisAns 2007). In Central Europe it is limited to southern Switzerland (HESs et al. 1970, LAUBER and WAGNER 1998), while in Germany and Austria it escaped from the culture, but has recently been thought to be extinct (LIPPERT 1995, SCHMEIL and FITSCHEN 2003). It can be found in all countries of the Balkan Peninsula, including Croatia (HRŠAK 1997), Bosnia and Herzegovina (BECK and MANNAGETTA 1903), Montenegro (Rohlena 1942), Albania (PAPARISTO et al. 1989), Serbia (JosiFOVIĆ 1972, KoJIĆ 2007), Macedonia (MicEVSKi 1998), Romania (RĂVĂRUT 1956), Bulgaria (JORDANOv 1970) and Greece (STRID 2009). The eastern border of its distribution is in western Turkey (Asia Minor) (RĂVĂRuT 1956, EgGLI 2003, 'T HART and EGGLI 2003,) and in the south it reaches northern Africa - Tunisia, Algeria (BONNIER 1919-1920, PotTIER-AlapeTiTe 1979) and Libya (JALAS et al. 1999). The occurrence of S. cepaea on Crete was recently reported by DESCHÂTRES and GREUTER (2001).

Sedum cepaea requires the least amount of light among Sedum species; therefore, it is most abundant in shady places such as the edges of forests and shrubberies, shadowed walls and rocks (LIPPERT 1995). It prefers fresh, nutrient and base rich, lime-deficient, moderately neutral to acidic, humic, stony or sandy clay soil (OBERDORFER 1994, LIPPERT 1995). Although it usually appears above limestone bedrock (EGGLi 2003, 'T HART and EGGLI, 2003), it often prefers siliceous rocks (BONNIER 1919-1920, FourniER 1961, PignATTI 1982, Castroviejo and Velayos 2001, Arrigoni 2010). In Central Europe Sedum cepaea grows mostly in lowlands within sciophilous and nitrophilous vegetation of Alliarion Oberd. (1957) $1962 \mathrm{em}$. Siss 1973 alliance, while in the subalpine belt it is frequent in plant communities dominated by mosses and liverworts (LIPPERT 1995). Elsewhere it can be found in woods as well, for example, in Serbia it is present in forest communities of the orders Qurcetalia pubescentis Br.-B1. 1932 (e.g. Quercetum frainetto-cerris Rudski 1940, Quercetum montanum (Jov. 1948) Černj. et Jov. 1953) and Fagetalia sylvaticae Pawl. 1928 (e.g. Fagetum montanum (Rudski 1949) Jov. 1967, Fagetum submontanum Mišić (1963) 1972) (Josifović 1972, KoJIĆ et al. 1997, KoJIĆ 2007). In Greece, it has been reported as a species constituting the Rodopi beech forest communities (TSIRIPIDIS and ATHANASIADIS 2003). There are three known cytotypes of S. cepaea, but they cannot be morphologically distinguished and do not differ in ecological preference or altitudinal range ('T HART 1991, EGGLI 2003, STRID 2009).

\section{Materials and methods}

In order to verify the localities where Sedum cepaea was recorded in literature and herbaria, field research was performed in the period from 2009 to 2011 . The research included three areas of Central Croatia - Nikolino brdo in Topusko and Moslavačka gora, as finding spots already known from literature and herbaria, and Zrinska gora, as a newly discovered finding spot of $S$. cepaea.

Moslavačka gora is a mountain 489 m a. s. 1. in the western part of the Croatian Pannonian Plain, built of igneous (granite) and metamorphic (gneiss) rocks giving rise to brown siliceous soils. Forest vegetation covers a large part of the mountain. Forests of sessile oak prevail, whereas beech is more common on northern slopes.

Nikolino brdo is a relatively small hill situated in the town of Topusko in Banovina Region. At the end of the $19^{\text {th }}$ and beginning of the $20^{\text {th }}$ century some of the famous older 
Croatian botanists (Rossi, Schlosser and Vukotinović) collected plant specimens there, which are deposited in the ZA herbarium. Nikolino brdo enjoys preventive protection and has been proposed for categorization as forest park.

Zrinska gora is a mountain located at the meeting point of two large relief units: the southern edge of the Pannonian Plain and the northern part of the pre-Dinaric space. Geologically, it is built out of Perm/Carbonian schists, sandstones and conglomerates, which are in the lower range covered with younger Tertiary deposits. It reaches a height of up to $616 \mathrm{~m}$. Most of the massif is covered with deciduous forests of oak, beech and chestnut, whereas the lower slopes feature pastures and arable land (BARIČEVIĆ et al. 2009, MEDAK 2009). The climate of the wider area is, according to the Croatian State Hydro-Meteorological Office, temperate warm and rainy.

The Gauss Krueger coordinates and altitudes of all finding spots were recorded on field using Garmin eTrex GPS device. In order to describe the habitat preferences of S. cepaea in Croatia, soil samples from all finding spots were taken and shadiness of the stands was estimated by the coverage of the tree layer. The soil was sampled at maximum depth of $10 \mathrm{~cm}$. Each finding spot was represented with three soil subsamples. Soil acidity in distilled water and in solution of potassium chloride was measured using a $\mathrm{pH} 330 \mathrm{i} \mathrm{pH}$ meter set.

\section{Results}

During the seasons of 2009 and 2010, small populations of Sedum cepaea consisting of only a few specimens were found at three localities on Zrinska gora (one at Bukova kosa and two at Jezičevac) (Figs. 1, 2). The populations were noticed in shaded forest stands dominated by sessile oak. An old finding spot of S. cepaea on Moslavačka gora (St. Benedict Hill) was confirmed during growing season 2010. Here, the species grew on more heliophilous habitats such as degraded forest of sessile oak or along forest roads near forest edges. In both cases the populations were more numerous than those found on Zrinska gora. The occurrence of S. cepaea on Nikolino brdo in Topusko was not confirmed during the research in 2010.

In addition, in 2011 two new finding spots of S. cepaea were recorded on Zrinska gora, again in the same type of forest and with a low number of specimens. On Moslavčka gora, one new finding spot (Kletište) was found also in 2011, on the edge of the forest, featuring again a high number of specimens.
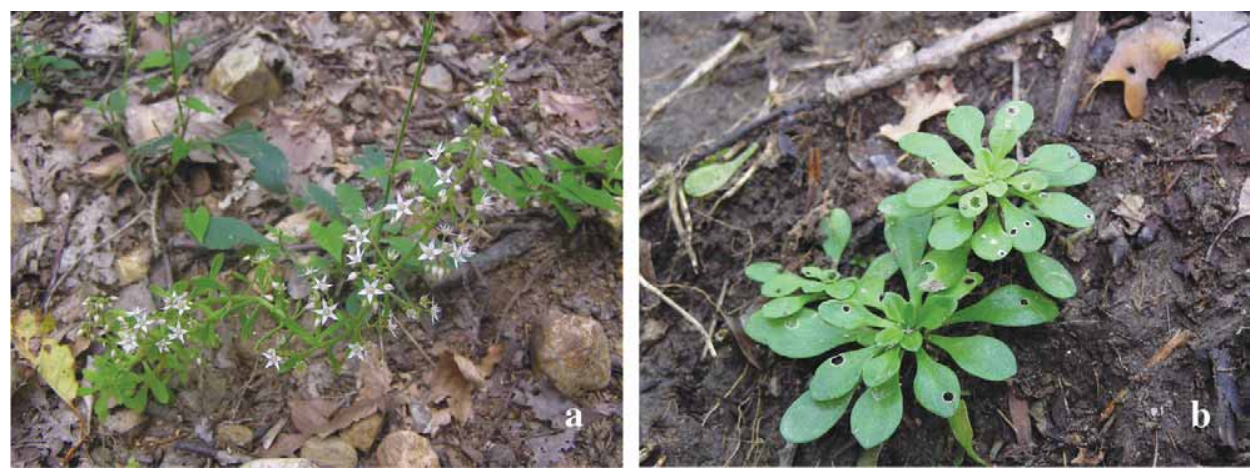

Fig. 1. Sedum cepaea; a - inflorescence (Zrinska gora), b - basal rosettes (Moslavačka gora), (photo by I. Šapić) 


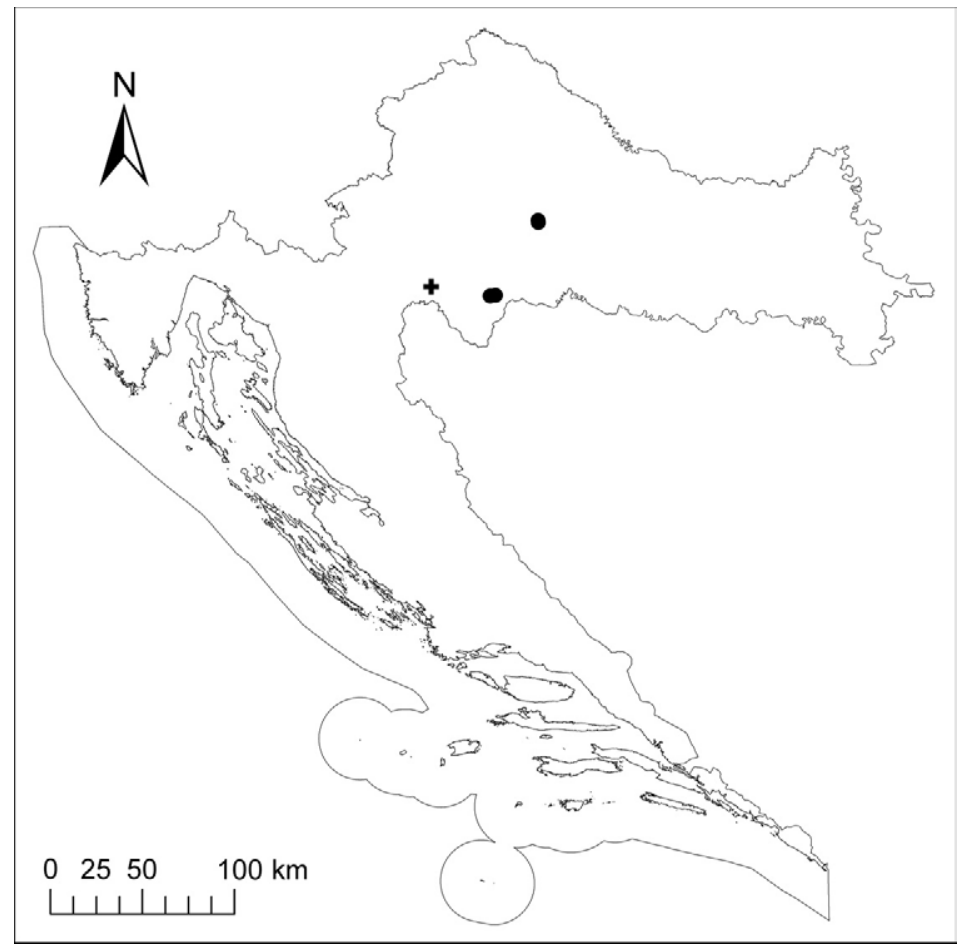

Fig. 2. Distribution of Sedum cepaea in Croatia. New and confirmed (•), and old unconfirmed (+) finding spots. Localities and data sources quoted in Appendix 1.

Tab. 1. Mean $\mathrm{pH}$ values of soil from findspots of Sedum cepaea in Croatia. $\mathrm{pH}_{\mathrm{H} 20}-\mathrm{pH}$ measured in soil suspension with distillated water, $\mathrm{pH}_{\mathrm{KCl}}-\mathrm{pH}$ measured in suspension with $1 \mathrm{M} \mathrm{KCl}$.

\begin{tabular}{lcc}
\hline Findspot (name of locality, habitat, GPS coordinates, altitude) & $\mathrm{pH}_{\mathrm{H} 20}$ & $\mathrm{pH}_{\mathrm{KCl}}$ \\
\hline $\begin{array}{l}\text { Moslavačka gora (St. Benedict Hill, degraded forest of sessile oak, 5634779, } \\
\text { 505276, } 320 \text { m a.s.) }\end{array}$ & 5.0 & 4.2 \\
$\begin{array}{l}\text { Moslavačka gora (St. Benedict Hill, along forest roads, 5634699, 5053488, } \\
\text { 332 m a.s.) }\end{array}$ & 5.3 & 4.4 \\
$\begin{array}{l}\text { Zrinska gora (Bukova kosa, acido-thermophilic forest of sessile oak, 5611517, } \\
\text { 5012903, } 403 \text { m a.s.) }\end{array}$ & 4.8 & 3.7 \\
$\begin{array}{l}\text { Zrinska gora (Jezičevac, acido-thermophilic forest of sessile oak, 5608568, } \\
\text { 5012489, } 441 \text { m a.s.;) }\end{array}$ & 5.0 & 4.0 \\
$\begin{array}{l}\text { Zrinska gora (Jezičevac, acido-thermophilic forest of sessile oak, 5608726, } \\
\text { 5012478, } 432 \text { m a.s.) }\end{array}$ & 4.7 & 3.7 \\
\hline
\end{tabular}

The Gauss Krueger coordinates and altitudes of the finding spots on Zrinska and Moslavačka gora are summarized in table 1 . In the same table, the mean $\mathrm{pH}$ values of soil for finding spots found in 2009 and 2010 are shown. 


\section{Discussion}

The recent findings of a few large populations of Sedum cepaea on Zrinska gora raised the issue of distribution of this rare species in Croatia. Therefore, a literature study, herbarium survey and verification of old, already known localities, were performed.

Literature study revealed only a few historical records of Sedum cepaea in Croatia: »Morinje, Lepetane et Perzagno propre Cattaro « (Visiani 1852, Schlosser and VukotiNOVIĆ 1869), »circa Semling « (SCHLOSSER and VuKotinović 1869) and Moslavačka gora (Čabranjski drum, Stara straža, Pleterac) by HrušKA-DELL' UOMO (1974), the first two of them, however, being no longer within Croatian territory. In Flora Croatica database (NIKOLIĆ 2010) beside record from Moslavačka gora, a record for Morinje near Šibenik is present (Milović 2002). In the herbarium of ZA barely five herbarium sheets with $S$. cepaea, collected on Moslavačka gora and in Topusko (Nikolino Brdo), were found.

First record on distribution of Sedum cepaea in Croatia was noted by VISIANI (1852) »in rupestribus umbrosis Morinje, Lepetane et Perzagno propre Cattaro, nec non circa Much «, and is cited later in Schlosser and Vukotinović (1869). These finding spots refer to the towns of Morinj, Lepetane and Prčanj near the town of Kotor, which were once within the borders of province of Dalmatia. Today, they are no longer within Croatian territory, but in Montenegro. The same is also with another finding spot cited by SCHLOSSER and VUKOTINOVIĆ (1869) »circa Semling « which refers to the town of Zemun in today's Serbia. It took a long time for another quotation of this species in Croatia. In 1971 it was found at only one locality on Moslavačka gora within sessile oak forest (ass. Festuco drymeiae-Quercetum petraeae Janković (1968) Hruška 1974)) (HRUŠKA-DELL'UOMO 1974). The old VISIANI record of S. cepaea in the surroundings of town of Šibenik (at Morinje) was not confirmed by Milović (2002), who actually misinterpreted Visiani's toponym Morinje (relating to Morinj near Kotor in Montenegro) as Morinje (near Šibenik in Croatia) and his misinterpretation entered the Flora Croatica Database (NIKOLIĆ 2010) where Morinje near Šibenik is cited as finding spot of this species.

In addition, a few herbarium specimens of $S$. cepaea, collected in the town of Topusko (Nikolino brdo) at the end of the $19^{\text {th }}$ century and on Moslavačka gora at the beginning of the $20^{\text {th }}$ century, are deposited in ZA herbarium. On Nikolino brdo $S$. cepaea was collected three times: by Schlosser in 1871, by Vukotinović in 1882 and by Rossi in 1888 (data from ZA). It is interesting that SCHLOSSER and VuKotinović (1876) have not included S. cepaea in »Bilinar - flora excursioria«. Vukotinović in shedula (no. 3552) discussed a possible horticultural origin of this population: »In pede monticoli »Nikolino brdo« in Topusko, copiosum in herbidis inibi ad marginem viae (promenadae), quae a Schlammbad ducit ad Spiegelbad. Sed per hortulanum ante pluros annos semine disjecto spontaneum modo copiosissimum. «Some of the specimens collected by Vukotinović were included in »Flora exsiccata austro-hungarica (no. 617) by KERNER, who pointed out (also in shedula) that the population from Nikolino brdo was not established through escape from gardens: »Da dieses Sedum als Zierpflanze bei den Gärtnern nie eine Rolle gespielt hat, ist eine derartige künstliche Ansiedelung und Einbürgerung aber wenig wahrscheinlich. Dagegen spricht der Umstand, dass S. Cepaea auch in anderen Florengebieten gewönlich nur auf sehr beschränkten Localitäten angetroffen wird, dafür, dass dasselbe eine in südlichen Croatien indigene Pflanze ist...«. But HIRC (1910) could not find this species again even as soon as 
in 1908. He made several excursions there during 1908 looking for S. cepaea and concluded that he was there »too early« in May, or »too late« in August.

To summarize, until this research, the only known finding spots of $S$. cepaea in Croatia based on literature and herbarium data were Moslavačka gora and Nikolino brdo in Topusko, with the existence of the latter being in doubt (Appendix 1).

Since a detailed search for S. cepaea on Nikolino brdo in 2010 did not reveal any results, it is obvious that this population has vanished, most probably a century ago. This is probably due to anthropogenic influence, since Nikolino brdo has been used an entire century as a recreation place. The population on Moslavčka gora (St. Benedict Hill), first found during a forest vegetation survey in 1974, was rediscovered in 2010 . This population represents the most numerous population of $S$. cepaea in Croatia. The only other population existing currently in Croatia is that found in 2009 on Zrinska gora by first author. This is the first record of this rare species in Zrinska gora and the Banovina region. Although the flora of the wider area of Zrinska gora has been already investigated by ŠEGULJA et al. (1998), resulting in a total of 682 taxa, S. cepaea was not found during that research. Here the population is much smaller, consisting of only a few specimens at three localities. On both finding spots (Moslavačka gora and Zrinska gora, respectively), S. cepaea grows in vegetation belt dominated by sessile oak. On Zrinska gora the species lives in the recently described association Potentillo micranthae-Quercetum petraeae Vukelić, Baričević et Šapić 2010 (VuKELIĆ et al. 2010). This is a floristically relatively poorer type of acido-thermophilic forest of sessile oak, predominantly developed on southern exposures, at heights between 300 and $500 \mathrm{~m}$. a. s., on luvisol and dystric cambisol.

The habitat of the population of S. cepaea on Zrinska gora is rather shaded due to denser tree canopy, while on Moslavčka gora the species is present in degraded forest stands and forest edges, characterized by somewhat more light. The noticed habitats are in accordance with those known from the literature, supporting the fact that $S$. cepaea is one of the most sciophilous Sedum species that can easily grow inside forest stands. All measurements of soil acidity indicate that $S$. cepaea prefers acidic substrata $\left(\mathrm{pH}_{\mathrm{H} 2 \mathrm{O}}\right.$ from $\left.4,7-5,3\right)$. These types of soil are developed above siliceous geological bedrock predominantly present on Moslavačka gora (HRUŠKA-DELL' UOMO 1974) and Zrinska gora. In Central Europe the species occurs on acidic soil too (LANDOLT, E. 2010) while, similarly, in Serbia, it has been categorized in the transitional group between acidophylous and neutrophylous plants (KoJÍ́ et al. 1997).

Taken together, the results of this research suggest that according to current knowledge $S$. cepaea is an extremely rare species in the Croatian flora, represented by only a few small populations, restricted to two mountain areas of Central Croatia (Moslavačka gora and Zrinska gora) (Fig. 2). Ecologically, it is limited to sciophilous or slightly heliophilous forest habitats in the zone dominated by Quercus petraea (300-450 m a.s.), developed on acidic types of soil above siliceous geological bedrock. Due to its rareness, there is a definite need for further investigation and protection of this species. Moreover if we consider the fact that it is a decoratively interesting plant, it is potentially at risk from collectors. According to IUCN criteria (ANONYMOUs 2010) S. cepaea could enter the category of near threatened (NT) species in Croatia. This is due to there being fewer than ten known, fragmented, localities, as well as to its extinction in one locality. Furthermore, the categorization is reevaluated according to the probability of propagule immigration from adjacent populations from the region. 


\section{References}

ANONYMUS, 2010: Guidelines for using the IUCN Red List Categories and Criteria. Version 8.1. Standards and Petitions Subcommittee of the IUCN Species Survival Commission. http://intranet.iucn.org/webfiles/doc/SSC/RedList/RedListGuidelines.pdf

Arrigoni, P. V., 2010: Flora dellâ isola di Sardegna, 2. Carlo Delfino, Roma.

BARIČEvić, D., Vukelić, J., ŠAPIĆ, I., 2009: Ass. Polysticho setiferi-Fagetum Zupančič et al. 2000 in forest vegetation of Zrinska Gora (Croatia). Hladnikia 23, 81-91.

Beck, V., Mannagetta, G., 1923: The Flora of Bosnia, Herzegovina and former region Novi Pazar cont (In Serbo-Croatian). Glasnik Zemaljskog Muzeja Bosni Hercegovini 35.

Bonnier, G., 1919-1920: Flore Complète illustrée en couleurs de France, Suisse et Belgique 4. Neuchatel, Paris, Brussels.

BonNIER, G., 1919-1920: Flore complète illustrèe en couleurs de France Suisse et Belgique, 4. Delachaux et Niestlé, Librarie Générale de l'Enseignement, J. Lebègue, Neuchatel.

Castroviejo, S., Velayos, M., 2001: Sedum. In: Castroviejo, S. (ed.), Claves de Flora Iberica. Plantas vasculares de la Península Iberíca e Islas Baleares, 1, Pteridophyta, Gymnospermae, Abgiospermae (Laureaceae - Euphorbiaceae), 451-457. Real Jardín Botánico, Madrid

Deschâtres, R., Greuter, W., 2001: Crassulaceae. In: Greuter, W., Raus, T. (eds.), Med-Checklist Notulae, 20. Willdenowia 31, 322.

EGGLI, U. (ed.), 2003: Illustrated handbook of succulent plants. Crassulaceae. Springer -Verlag, Berlin.

FourniER, P., 1961: Les Quatre Flores de la France. Corse comprise (Générale, Alpine, Méditerranéenne, Littorale). Editions Paul Lechevalier, Paris.

Hess, H. E., Landolt, E., Hirzel, R, 1970: Flora der Schweiz und angrenzender Gebiete 2. Nymphaeceae - Primulaceae. Birkhäuser Verlag, Basel.

HIRC, D., 1910: The revision of Croatian Flora (In Croatian). Rad Jugoslavenske Akademije znanosti i umjetnosti 183, 726-807.

HrŠAK, V., 1997: Sedum. In: NikOLIĆ, T. (ed.), Flora Croatica-Index Florae Croaticae 2. Natura Croatica 6. Suppl. 1, 45.

HrušKa-Dell'uomo, K., 1974: The vegetation of Moslavačka gora (In Croatian). Ph.D. Thesis, University of Zagreb, 1-312.

Jalas, J., Souminen, J., Lampinen, R., Kurrto, A., (eds.) 1999: Atlas Florae Europaeae. Distribution of vascular plants in Europe 12. Resedaceae to Platanaceae. The Committee for Mapping the Flora of Europe, Societas Biologica Fennica Vanamo, Helsinki.

Jeanmonod, D., Gamisans, J., 2007: Flora Corsica. Édisud, Aiy-en-Provence.

Jordanov, D. (ed.), 1970: The flora of the People Republic of Bulgaria 4 (In Bulgarian). Bulgarska akademija na naukite, Sofia.

Josifović, M. (ed.), 1972: The flora of the Socialist Republic of Serbia (In Serbian), 4. Srpska akademija nauka i umetnosti. Odelenje prirodno-matematičkih nauka, Belgrade.

KoJIĆ, M., 2007: The excursion flora of Serbia (In Serbian). NNK international, Belgrade. 
KoJIĆ, M., Popović, R., KARADžıć, B., 1997: Vascular plants of Serbia as habitat indikators (In Serbian). Institut za istraživanje u poljoprivredi »Srbija«, Institut za biološka istraživanja »Siniša Stanković«, Belgrade.

LANDOLT, E., 2010: Flora indicativa. Ökologische Zeigwerte und biologische Kennzechen zur Flora der Schweiz und der Alpen. Editions des Conservatoire et Jardin botaniques de la Ville de Genève, Haupt Verlag Bern-Stuttgart-Wien.

Lauber, K., Wagner, G., 1998: Flora Helvetica, 2. Verlag Paul Haupt, Bern-Stuttgart-Wien.

LiPPERT, W., 1995: Sedum. In: HeGi, G. (ed.), Ilustrierte Flora von Mitteleuropa 4 (2a). Spermatophyta - Angiospermae - Dicotyledones 2 (2), 111-112. Blackwell Wissenschafts Verlag. Berlin.

MedAK, J., 2009: Forest communities and habitats of chestnut (Castanea sativa Mill.) in Croatia (In Croatian). Ph.D. Thesis, University of Zagreb, 1-168.

Micevski, K., 1998: The flora of the Republic of Macedonia1(4) (in Macedonian). Makedonska akademija na naukite i umetnostite, Skopje.

Milović, M., 2002: The flora of Šibenik and its surroundings. Natura Croatica 11, 171-223.

Nikolić, T. (ed.), 2010: Flora Croatica Database. Department of Botany and Botanical Garden, Faculty of Science, University of Zagreb. http://hirc.botanic.hr/fcd, accessed November 2010.

OBERDORFER, E., 1994: Pflanzensociologische exursionsflora. Verlag Eugen Ulmer, Stuttgart.

PAparisto, K., Demiri, M., Mitrushi, I., Qosja, X., 1989: The flora of Albania. 1. Lycopodiaceae - Plantaginaceae (In Albanian). Akademia e shkencave e RPS te Shqipërisë, Tirana.

PignatTI, S., 1982: Flora d'Italia, 1. Edizioni Agricole, Bologna.

Pottier-Alapetite, G., 1979: Flore de la Tunisie, 1. Angiospermae - Dicotyledones. Apetales - Dialypetales. Publications Scientifiques Tunisiennes. Programme flora et vegetation Tunisiennes, Tunisie.

RĂVĂRut, M, 1956: Sedum cepaea L. In: SĂvulescu, T. (ed.), The flora of the People's Republic of Romania (in Romanian) 4, 66-69. Academia Republicii Populare Romî, Bukurest.

Rohlena, J., 1942: Conspectus Florae Montenegrinae. Preslia 20/21, 128.

Schlosser, J., Vukotinović, Lj., 1869: Flora Croatica, Zagrabiae.

Schlosser, J., Vukotinović, LJ., 1876: Determination key for plants. Flora excursioria. Introduction to collecting and determination of plants in Croatia, Slovenia and Dalmatia (In Croatian). JAZU, Tisak L. Hartman, Zagreb.

SchmeIL, O., Fitschen, J., 2003: Flora von Deutschland und seine angrenzenden Gebieten. Quelle Meyer Verlag, Heidelberg, Eiesbaden.

Strid, A., TAn. K. (eds), 2009: Mountain Flora of Greece, 1, 1. Cambridge University Press, Cambridge.

ŠEgulJa, N., ILIJANić, LJ., MARKović, LJ., 1998: Overview and analyses of flora of Zrinska gora (In Croatian). Acta Botanica Croatica 55/56, 65-99. 
'T Hart, H., EgGLI, U., 2003: Sedums of Europe. Stonecrops and Wallpeppers. A. A. Balkema Publisher, Lisse.

'T HART, H., 1991: Evolution and classification of the European Sedum species (Crassulaceae). Flora Mediterranea 1, 31-61.

Tsiripidis, I., AthANASIADIS, N., 2003: Contribution to the knowledge of the vascular flora of NE Greece: Floristic composition of the beech (Fagus sylvatica L.) forests in the Greek Rodopi. Wildenovia 33, 273-297.

VISIANI, R., 1852: Flora Dalmatica, Lipsiae.

VuKelić, J., BARIČEVIĆ, D., ŠAPIĆ, I., 2010: Nomenclatural-phytocoenological analysis of the association Potentillo micranthae-Quercetum petraeae ass. nova in Croatia. Haquetia 9, 5-17.

Webb, D. A., Akeroyd, R., T'Hart, H., 1993: Sedum. In: Tutin, T. G., Burges, N. A., Chater, A. O., Edmonson, J. R., Heywood, V. H., Moore, D. M., Valentine, D. H., Walters, S. M., WebB, D. A. (eds.), Flora Europaea 1, 429-436. Cambridge University Press, Cambridge.

ZÁngheri, P., 1976: Flora Italica, 1 (Pteridophyta - Spermatophyta). Cedam - Casa editrice dott. Antonio Milani, Padova.

\section{Appendix 1. Herbarium localities of Sedum cepaea in Croatia.}

\section{SPECIMINA VISA}

Schlosser, J.: Ad vias ad termas Topuskensis, 1871 (ZA); Vukotinović, J.: In pede monticule »Nikolino brdo« in Topusko, 1882 (ZA); Vukotinović, J.: Na području Nikolino brdo u Topuskom, 1882 (ZA); Rossi, L.: Ad pedem monticule ad Topusko, 1888 (ZA); Hirc, D.: Moslavina, Na šumskim čistinama Sv. Benedikta (brdo) kod Jelovske gornje, 1911 (ZA); Šapić, I.: Kletište, Moslavačka gora, 2011 (ZA) 